\title{
Modern Dünyada Kültürel Bir İnşa Olarak Noel
}

\author{
Hicret Kiraz Toprak
}

\author{
Dr., Ankara Sosyal Bilimler Üniversitesi (ROR ID: 025y36b60) \\ İslami İlimler Fakültesi, Din Sosyolojisi Anabilim Dalı \\ Assistant Professor, Social Sciences University of Ankara, Faculty of Islamic Studies, Department of \\ Sociology of Religion \\ Ankara/Turkey \\ hicret.toprak@asbu.edu.tr \\ ORCID: 0000-0002-4821-8768
}

\section{Christmas as a Cultural Construct in the Modern World}

\begin{abstract}
As the products of diligent human effort in understanding his own existence and the universe myths have come to be regarded as part of an archaic world in the modern age. In spite of the foresight that the 'enchanting' conception of the world would gradually disappear during the process of secularization, religous beliefs and mythological concepts have sustained themselves in the modern world with renewed forms and functions. In this context, the most common rituals of the Western Christian world are Christmas and the cults rebuilt around it.

The main focus of this study is the reconstruction of Christmas as a part of the capitalist culture industry, which continues to exist with all its vitality in the modern world, where sanctity is attributed only to the production of reason-based methodical knowledge, and all categories outside the rational field are at most reduced to the category of fiction or superstition. Indeed, the secular imagination of the modern age and the religious and 'archaic' origins of Christmas reflect a remarkable contradiction at first glance.

The historical origins of Christmas as the common cultural heritage of the Christian West is based on pagan beliefs of Ancient Rome and Iran along with Christian syncretism. The mysterious religions of the East had greatly penetrated the beliefs of the public sphere when Christianity began to spread in the vast geography under the domination of the Roman Empire. During this process, the dominant cults and sacred figures of pagan traditions, which had spread over a wide period of time and space, are the products of a multicultural syncretism, continued living on by infiltrating Christianity with their strong symbolism. Mithraism, which has been included in the Christian tradition by the Church fathers from the beginning of the 4th century, is one of them. The transitions between Christianity and the pagan traditions of Mithraism gain clearance first and foremost December 25th, identified by the birthday of Jesus, in the example of Christmas.

However, the secular form of Christmas that brings together the sacred and profane elements peculiar to needs of the modern age, which in the modern age is almost reinvented in accor-
\end{abstract}

İntihal Taraması/Plagiarism Detection: Bu makale intihal taramasından geçirildi/This paper was checked for plagiarism Etik Beyan/Ethical Statement: Bu çalışmanın hazırlanma sürecinde bilimsel ve etik ilkelere uyulduğu ve yararlanılan tüm çalışmaların kaynakçada belirtildiği beyan olunur/It is declared that scientific and ethical principles have been followed while carrying out and writing this study and that all the sources used have been properly cited (Hicret Kiraz Toprak).

Geliş/Received: 25 Haziran/June 2021 | Kabul/Accepted: 18 Eylül/September 2021 | Yayın/Published: 20 Eylül/September 2021

Atıf/Cite as: Hicret Kiraz Toprak, Modern Dünyada Kültürel Bir İnşa Olarak Noel = Christmas as a Cultural Construct in the Modern World", Eskiyeni 44 (Eylül/September 2021), 663-678. https://doi.org/10.37697/eskiyeni.957345

CC BY-NC 4.0 | This paper is licensed under a Creative Commons Attribution-NonCommercial License 
dance with the needs of capitalist society in which cultural production has turned into an "industry", can only be understood in the instrumental functionality it has gained in the context of the culture industry. The foresight that man and society can be reconstructed within the framework of the rising values of the Enlightenment has made cultural production one of the industries in the commodity production sector in the modern age. A typical example of this is the popular Christmas literature developed from the 19th century, combining sacred elements and profane values.

The global-based spread of Christmas today is closely related to the 'consumption culture' that the capitalist system has created as a new and unique communalization style. So much so that the representation and images produced by the consumption industry of Christmas have gained a global character, especially the figure of Santa Claus, which has become the global icon of huge shopping centers during Christmas week. After all, Christmas today stands out as a cultural construction of the modern world and one of the most widespread examples of the global commercial diffusion of capitalism.

\section{Keywords}

Sociology of Religion, Modernity, Christmas, Myth, Cultural Construction, Fakelore

\section{Öz}

\section{Modern Dünyada Kültürel Bir İnşa Olarak Noel}

Tarihin en eski çağlarında insanın kendi varlığını ve evreni anlama çabasının ürünü olarak ortaya çıkan mitler, modern dönemde arkaik bir dünyanın parçası olarak ele alınmıştır. Dünyanın "büyülü" evreninin sekülerleşme etaplarında aşamalı olarak ortadan kalkacağı öngörüsüne rağmen dinsel inançlar ve çeşitli mitolojik tasavvurlar, modern dünyada da yeni form ve işlevlerle varlığını sürdürmüştür. Bu kapsamda Hristiyan Batı dünyasının en yaygın ritüellerinin başında Noel ve onun etrafında yeniden inşa edilen kültler gelmektedir.

Kutsallığın yalnızca akıl temelli metodik bilgi üretimine atfedildiği, rasyonel alanın dışında kalan bütün kategorilerin ise olsa olsa birer kurmaca yahut batıl inanç kategorisine indirgendiği modern dünyada bütün canlılı̆̆ıyla varlığını sürdüren Noel'in, kapitalist kültür endüstrisinin bir parçası olarak yeniden inşası bu çalışmanın ana problemidir. Gerçekten de modern çağın seküler tahayyülü ile Noel'in dinsel ve "arkaik" kökenleri ilk bakışta kayda değer bir çelişkiyi yansıtmaktadır.

Hristiyan Batı dünyasının ortak kültürel mirasına yaslanan Noel'in tarihsel kökenleri antik Roma ve İran pagan inançlarıyla Hristiyanlığın senkretizmine dayanmaktadır. Doğu'nun gizem/sır dinleri, Hristiyanlığın Roma İmparatorluğunun hakimiyeti altındaki geniş coğrafyada yayılmaya başladığı sırada, halk katındaki inançlara büyük oranda nüfuz etmiş bulunuyordu. Geniş bir zamana ve mekâna yayılan ve çok kültürlü bir senkretizmin ürünü olan pagan geleneklerin baskın kültleri ve kutsal figürleri, bu süreçte güçlü sembolizmleri sayesinde Hristiyanlığın içine sızarak yaşamaya devam etmiştir. 4. yüzyılın başlarından itibaren Kilise babaları tarafından Hristiyan geleneğine dahil edilen Mithraizm, bunların başında gelmektedir. Başta İsa'nın doğum günü ile özdeşleșen 25 Aralık günü başta olmak üzere Hristiyanlık ile Mithraizm'in pagan gelenekleri arasındaki geçişler Noel örneğinde açıklık kazanmaktadır.

Ne var ki modern çağda kültürel üretimin bir “endüstri”ye dönüştüğü kapitalist toplumun ihtiyaçlarına uygun olarak adeta yeniden icat edilen Noel'in, modern çağa özgü kutsal ve profan ögeleri bir araya getiren seküler formu, kültür endüstrisi bağlamında kazandığı araçsal işlevsellik içinde ancak anlaşılabilir. İnsanın ve toplumun Aydınlanma'nın yükselen değerleri çerçevesinde yeni baştan kurgulanabileceği öngörüsü, modern çağda kültürel üretimi meta üretimi sektöründeki endüstrilerden birisi haline getirmiştir. 19. yüzyıldan itibaren geliștirilen 
ve kutsal ögelerle profan değerleri mezceden popüler Noel edebiyatı, bunun tipik bir örneğidir.

Noel'in günümüzdeki küresel bazlı yayılımı ise kapitalist sistemin yeni ve özgün bir toplumsallaşma tarzı olarak ortaya çıardığı “tüketim kültürü”yle yakından ilgilidir. Öyle ki Noel haftasında devasa alışveriş merkezlerinin küresel ikonu haline getirilen Noel Baba figürü başta olmak üzere, Noel'in tüketim endüstrisi tarafından imal edilen temsil ve imajları küresel bir nitelik kazanmıştır. Nihayetinde bugün Noel, modern dünyaya ait kültürel bir inşa ve kapitalizmin küresel ticari yayılımının en yaygın örneklerinden birisi olarak öne çıkmaktadır.

\section{Anahtar Kelimeler}

Din Sosyolojisi, Modernite, Noel, Mit, Kültürel İnşa, Fakelore

\section{Giriş}

İnsanın evreni ve kendi varlığını anlama çabasının bir ürünü olarak tarihin en eski çağlarında ortaya çıktıkları düşünülen mitler, "yaratılış"a dair "kutsal” bir öyküyü canlandırmaktadır. Mitlerin gizemli evreninde dünyayı gerçek anlamda kuran ve onu içinde bulunduğu duruma getiren, "kutsal"'ın dünyaya çeşitli düzeylerde yol bulan heyecan verici akınlarıdır. ${ }^{1}$ Modern çağda insana özgü karmaşık kültürel olgular olarak ele alınan mitlerin tarihin belirli bir evresinde insan düşüncesinden doğmuş olan birtakım tasavvurlardan kaynaklandığı düşüncesi ağırlık kazanmıştır. Buna göre geçmişe ait arkaik bir tasavvur dünyası içinde betimlenen mitlerin "büyülü" evreni, uygarlığın gelişim ve "ilerleme” aşamalarına bağlı olarak açıklama güçlerini yitirecek, "akıl” ve "bilim"in egemenliği altındaki "yeni bilme biçimleri” benimsenecektir. Ne var ki mitlerin gizemli evreni modern çağın seküler ve akılcı tabiatına rağmen yaşam formlarında ve pratiklerinde çeşitli biçimlerde tezahür etmeye devam etmiştir. Ancak biz burada ne yalnızca geniş halk kitlelerinin kültürel hafızasında yaşayan eski çağ inançlarına ait kalıntılardan ne de modern dünyada ortaya çıkan "kargo kültleri” gibi birtakım seküler mitlerden söz ediyoruz. Bizim peşine düştüğümüz esas soru, mitsel inanç ve ritüellerin olsa olsa bir "kurmaca" yahut "batıl inanç" kategorisine indirgendiği "büyüsü bozulmuş” bir dünyada, birtakım geçmiş kalıntılarına nasıl olup da özenli bir şekilde yer açılmış olduğudur. Bu geçmiş kalıntıları arasında Hristiyan Batı dünyasının en yaygın dinsel ritüellerinin başında "Noel"2 ve onun etrafında yeniden inşa edilen "kült"ler gelmektedir.

Noel'in Hristiyanlık öncesi dönemlere uzanan kökleri Antik dünyanın pagan inançlarına kadar takip edilebilse bile, bu kökler onun modern çağın seküler tabiatı içinde kazandığı yeni görünümleri açıklamak için yeterli değildir. Gerçekten de ta-

1 Mircea Eliade yaşadığımız dünyadan bütünüyle farklı, bu dünyaya ait olmayan bir gerçeğin, doğal ve profan dünyaya ait nesnelerde açığa çıkması olarak tanımladığı "kutsalın tezahürü” (hierophanie) kavramsallaştırmasını kullanır. Bir nesneye kutsallık atfettiğimizde, o nesne artık "kutsal"ın kendisinde açığa çıktığı bir gerçekliktir. Kutsal ve Dindışı (Ankara: Gece Yayınları, 1991); a.mlf. Mitlerin Özellikleri (Isstanbul: Alfa Yayınları, 2016), 16.

2 Hristiyan dünyasında Hz. İsa'nın doğum günü olarak kabul edilen ve bugün küresel olarak "yılbaşı" kutlamalarıyla özdeşleşen Noel kavramı dilimize Fransızcadan (Noël) geçmiştir. Kavramın Latince ve Batı dillerindeki kullanımları için bk. H. J. Hillerbrand, "Christmas", Encyclopedia Britannica (Erişim 17 Haziran 2021). https://www.britannica.com/topic/Christmas. 
rihsel süreci takip ettiğimizde Noel, öncelikle seküler toplum tahayyülünün kurucu bir bileşeni olarak yeniden kurgulanmış, ardından da yeni bir form ve işlevsellik içinde kapitalist kültürün küresel yayılımının esaslı bileşenlerinden birisi haline getirilmiştir. İşte bu makalede Noel'in 18. yüzyıldan itibaren elde ettiği yeni görünümler kültürel bir inşa olarak ele alınmakta ve bu inşanın dinamikleri çözümlenmeye çalışılmaktadır.

\section{Noel'in Pagan Kökleri}

Noel'in Hristiyanlık öncesi kökenleri bizi antik Roma ve İran senkretik kültürlerinin pagan dünyasına götürmektedir. Hristiyanlığın Roma İmparatorluğunun hakimiyeti altındaki geniş coğrafyada yayılmaya başladığı sırada bu coğrafyada yüzyıllar boyunca Doğu'nun gizem/sır dinleri (mysteria, initia) halk katındaki inançlara büyük oranda nüfuz etmiş bulunuyordu. Bu düşünceye göre geniş bir zamana ve mekâna yayılan çok kültürlü bir senkretizmin ürünü olan pagan gelenekler, güçlü sembolizmleri sayesinde Hristiyanlığın içine sızarak yaşamaya devam etmiş olmalıdır. Tabiat olaylarının insanın kudret ve sınırlarını aşan mucizevi akışı karşısında paganist inançlar; doğa üstü güçlere ve birbiri içine geçmiş mistik karakterli efsanevi kültlere kaynaklık ediyordu. Gizem dinlerinin bu mitolojik evreni, çok geniş bir zaman ve mekân boyutunda farklı inanç ve kültürlerin kalıplarına uyum sağlayarak varlığını sürdürebilecek derecede güçlü bir karaktere sahipti. Bu dinler katı bir biçimsellikle malul olan Roma devlet dininin aksine müntesiplerinin kendi seçtikleri tanrıya yakınlaşarak ruhların arındırmalarına olanak tanıyor, onlara ölümden sonra kutsal ve sonsuz bir yaşam vaat ederken, aynı zamanda tanrılarına bu dünyada iken yakınlaşma umudunu da bahşediyordu. ${ }^{3}$ Eski İran dinlerinin mistik mirasıyla Yunan ve Roma mitolojilerini mezceden bir tür senkretizm konumundaki Mithraizm bunların başında gelmekteydi. ${ }^{4}$ Imparatorluk çağına özgü çeşitli tinsel akımların birtakım eskatolojik unsurlarını güneş tektanrıcılığıyla birleştirerek güçlü bir senteze ulaşmayı başaran Mithraizm, dönemin diğer gizem dinleri arasında disiplin, kanaat ve ahlak anlayışıyla öne çıkıyordu. Öyle ki Hristiyanlığın bu coğrafyada yayılmaya başladığı dönemde Mithraizm, kuzeyde ve batıda İngiltere'den, güneyde ve doğuda Filistin'e kadar genişlemiş durumdayd..$^{5}$ Özellikle Roma, Mithras kültlerinin yayılması konusunda oldukça elverişli bir zemin sağlamış, İmparatorluk döneminde diğer gizem dinleri yıkıldığ halde Mithraizm, Hristiyanlığı benimseyenler arasında da bir müddet yaşamaya devam etmiştir.

3 Çiğdem Dürüşken, Antikçağda Yaşamin ve ölümün Bilinmezine Yolculuk Roma’nın Gizem Dinleri (isstanbul: Arkeoloji ve Sanat Yayınları, 2000), 44-47.

4 Ernest Renan Hristiyanlı̆̆ın doğduğu yıllarda ortadan kalkmış olması durumunda, bugün dünyanın Mithras dininde olacağını söyler. Renan'ın bu varsayımı abartılı olsa da Mithraizm'in Hristiyanlık öncesi yaygın ve güçlü konumuna dikkat çekmektedir. Roma'da gizem dinlerinin yayılışı hakkında bk. Dürüşken, Antikçağ’da Yaşamın ve Ölümün Bilinmezine Yolculuk Roma’nın Gizem Dinleri; ayrıca Mithraizm hakkında bk. Franz Cumont, The Mysteries of Mithra, çev. Thomas J. McCormack (New York: Cosimo Classics, 2007).

5 Dürüşken, Antikçağ’da Yaşamın ve ölümün Bilinmezine Yolculuk Roma'nın Gizem Dinleri, 148; Eliade, Mithra tapınaklarına özellikle eski Roma eyaletlerinden Daçya, Pannonia ve Germania'da rastlandığını kaydetmektedir. Dinsel İnançlar ve Düşünceler Tarihi II (İstanbul: Kabalcı Yayınları, 2000), 371. 
Yaygın görüşe göre Mithraizm’in baskın kültleri ve kutsal figürleri 4. yüzyılın başlarından itibaren yerleşik pagan geleneklere karşı Hristiyanlığı korumak ve bu efsanevi kişilikler aracılığıyla topluma ideal arketipler sunmak amacıyla Kilise babaları tarafından Hristiyan geleneğine dahil edilmiştir. ${ }^{6}$ Başta Hz. İsa'nın görsel tasvirleri olmak üzere Hz. Meryem ve bazı Hristiyan azizleriyle ilgili kutlamalar bu çerçevede Hristiyanlıkla bağdaştırılan uygulamalar olarak görünmektedir. Nitekim Mithraizm'in en eski tapınaklarına Roma'da rastlanması, ölümsüz Tanrı Mithra ile Hristiyanlığın İsa tasavvuru arasındaki bazı ortak yönleri ve şaşırtıcı benzerlikleri de açıklığa kavuşturmaktadır. Bu güçlü senkretizmin panteonunda klasik dünyanın belli başı Tanrıları yer alırken, bunlar arasında özellikle Mithra, ölümü tatmamış tek Tanrı olarak yüceltilmektedir. İnsanların günahlarını kendi yükü olarak taşıdığına ve bir gün onların yargıcı olarak yeryüzüne döneceğine inanılan Mithra, iyi ve kötünün savaşında insanlığın kuruluşu için cennetten sürülmüş bir "mesih"tir." Efsaneye göre ölümsüz güneş Tanrısı Mithra, tahta çıkmadan bir gün önce mağaraya çekilen Kral'ın bedeninde yeniden doğmakta ve bedenlenmekteydi. Başka bir deyişle Kral, yeniden doğup bedenlenmiş Mithra'dan başkası değildi. ${ }^{8}$ Beytüllahim mağarasında İsa'nın doğumunu betimleyen görsel temsil ve efsaneler, güneş Tanrısı Mithra'nın yeniden doğuş mitleriyle güçlü benzerlikler taşıyordu. ${ }^{9}$ İsa'nın doğumu da Roma Kilisesi tarafından 4. yüzyılın başlarında güneş Tanrısı Mithra'nın doğum günüyle (Dies Natalis solis invicti) bağdaştırılarak önce Roma Kilisesi'nde ardından da diğer kiliselerde 25 Aralık günü kutlanmaya başlamıştı. ${ }^{10}$

Noel'in ana unsurlarından birisi olan çam ağacının kökeniyle ilgili görüşler de çeşitli mitlerle ilişkilendirilmektedir. Eski Yunan ve Roma pagan mitlerinde ölümün ve yeniden doğuşun arketipleri olarak karşımıza çıkan ağaç figürleri, çeşitli Tanrıların ya da ataların ruhlarına ilişkin bir dirilişi sembolize etmektedir. Bu Tanrılardan birisi

6 İmparator Diocletanius, Galeirius ve Licinius Mitharizm'in baskın kültlerini halk katında yaşatmayı tercih etmiş, hatta imparatorluğun koruyucusu olarak seçtikleri bir mabedi de Mithras'a adamışlardı. Ancak 306 yılında tahta çıkan Konstantinos Hristiyanları himayesine alınca Mithraizm'in devlet katındaki gücü de yavaş yavaş azalmaya başlamıştır. Dürüşken, Antikçağ’da Yaşamın ve ölümün Bilinmezine Yolculuk Roma'nin Gizem Dinleri, 159. Konstantinos, 313 tarihli Milan Fermanıla Hristiyanlar üzerindeki devlet baskısını kaldırmış, 380 yılında I. Theodosios döneminde ise Hristiyanlık, Roma devletinin resmi dini olarak kabul edilmiştir. bk. Kürşat Demirci, "Hıristiyanlık", Türkiye Diyanet Vakfi İslam Ansiklopedisi (istanbul: TDV Yayınlar1, 1998), 17/332.

7 Dürüsken, Antikçă̆'da Yașamin ve Ölümün Bilinmezine Yolculuk Roma’nın Gizem Dinleri, 156.

8 Clement A. Miles, Christmas Customs and Traditions, Their History and Significance (New York: Dover Publications, 2011), 23; Eliade, Dinsel İnançlar ve Düşünceler Tarihi, 367.

9 Ayrıca Hristiyanlık ve Mithraizm arasında dünyanın sonu, kıyamet ve ölülerin dirilişiyle ilgili inanç motifleri hakkında bk. Eliade, Dinsel İnançlar ve Düşünceler Tarihi, 367-371.

$10 \mathrm{~Hz}$. İsa'nın doğum yılı ve günü kesin olarak bilinmemekte ve ilgili literatürde birbirinden oldukça farklı tarihlere ișaret edilmektedir. Owen Chadwick, A History of Christianity (New York: Thomas Dunne Books, 1995), 22. Ayrıca 25 Aralık gününün hangi tarihten itibaren Hz. İsa'nın doğum günü olarak kabul edildiği hakkında farklı görüşler için bk. Hillerbrand, "Christmas", Encyclopedia Britannica (Erişim 17 Haziran 2021), Chadwick, A History of Christianity (Macmillan, 1998), 22; Hidayet Işık, "Dini Kökeni Açısından Noel ve Yllbaşı", Necmettin Erbakan Üniversitesi ilahiyat Fakültesi Dergisi 7 (1997), 447; Mehmet Katar, "Hristiyanlık'ta İsa'nın Doğumu ile İlgili Kutlamaların Ortaya Çıkışı", İslamiyat 3/4 (2000), 117-123. 
olan bereket Tanrısı Attis'in çam ağacında yeniden vücut bulması eski Yunan ve Roma mitlerinde karşımıza çıkmaktadır. ${ }^{11}$ Son olarak Noel ağacının kökeni İskandinav halkları arasında hem ölülerin bayramı hem de bereket ve hayatın yüceltilmesi için kutlanan Yule festivalleriyle de ilişkilendirilmektedir. ${ }^{12}$ Kuzey Avrupa'da ölülerin, canlıların etrafında toplandığı yılın yeniden dirilişinin, baharın yeniden gelişinin temsil edildiği kış gündönümünde kutlanan Yule şenliklerinde, doğanın yeniden uyanışını ve ölümsüzlüğü temsil eden çam ağaçları ışıklandırılarak süslenirdi. ${ }^{13}$

Noel kutlamalarıyla özdeşleşen Aziz Nikolas (Santa Claus) figürü ise çok daha yakın bir dönemde bu geleneğe eklemlenmiştir. Aziz Nikolas'in 4. yüzyılda Roma İmparatorluğunun sınırları içinde bulunan Antalya'da yaşadığı hem sağlığında hem de öldükten sonra pek çok mucizeler gösterdiği ve bir görüşe göre de 11. yüzyılda cesedinin İtalyan tüccarlar tarafından İtalya'nın Bari kasabasına götürüldüğü kabul edilmektedir. ${ }^{14} \mathrm{Ne}$ var ki, Noel Baba (Father Christmas) olarak da bilinen Aziz Nikolas'in tarihsel şahsiyetiyle modern dönemde yeniden inşa edilen efsanevi karakteri birbirinden oldukça farklıdır.

\section{Aydınlanma Düşüncesi ve Mitler}

Aydınlanma düşüncesi, toplumsal/siyasal düzeni kontrol ve baskı altında tutan Kilise otoritesine karşı bir başkaldırı, evrenin ve içindekilerin açıklanmasında teolojik ilkelerin terk edilmesi ve birtakım "karanlık güçler"e karşı kendi kaderini tayin eden "akıl" ve "bilim"in öncülüğünde yeni bir insan tanımına dayanmaktadır. Eski mitolojik inançları değersizleştiren ve dinlerin otoritesini şüpheli hale getiren bir bütünlük içinde Aydınlanma düşünürlerinin programı, dünyanın her türlü gizden kurtarılarak mitlerin parçalanmasını ve "ham hayaller"in "bilgi"yle alaşağı edilmesini öngörüyor$\mathrm{du} \cdot{ }^{15}$ Teoloji, felsefe, siyaset ve bilimin sentezine dayalı düşünme biçimleri Aydınlanma sürecinde giderek geçerliliğini kaybediyor, dinlerin "aşkın" temellerine yönelik sorgulamalar teolojik kavramların "eski" ve "yeni" yi bağdaştırma niteliğini zayıflatıyordu. ${ }^{16}$ Böylece Tanrı merkezli teoloji anlayışından insan merkezli bir anlayışa yönelişin hakim hale geldiği modern çağın entelektüel atmosferinde dinler, dışarıdan bağımsız olarak incelenmesi gereken toplumsal fenomenlere dönüştürülürken, dinsel inançlar da ilahi olanın teorik bilgisi ya da bilimi olarak bir önerme statüsüne indirgeniyordu. ${ }^{17}$ Tarihsel kökenleri ve etkileri açısından bilimin nesnesi durumuna getirilen dinlerin -toplumu

11 Bülent Senay, “Noel”, Türkiye Diyanet Vakfi İslam Ansiklopedisi (Ankara: TDV Yayınlar1, 2007), 33/201.

12 Miles, Christmas Customs and Traditions, Their History and Significance, 171-2.

13 Eliade, Dinsel İnançlar ve Düşünceler Tarihi, 416.

14 Şenay, tüccarların, denizcilerin, gezginlerin ve çocukların azizi olduğuna inanılan Aziz Nikolas kültünün kısa sürede başta Yunan ve Rus Kiliseleri olmak üzere İtalya, Almanya, Avusturya ve Hollanda'da yaygınlık kazandığını kaydetmektedir. bk. "Noel”, 201.

15 Theodor W. Adorno-Max Horkheimer, Aydınlanmanın Diyalektiği (İstanbul: Kabalcı Yayınları, 1995), 19.

16 17. yüzyılın sonlarından itibaren Avrupa ticaretinin ve emperyalizmin yayılması, büyük uluslararası tekellerin hızla büyümesi, yeni teknolojilerin keşfedilmesi, yeni bir toplumsal farklılaşmanın ve akışkanlığın ortaya çıkması bu sürecin maddi koşullarını oluşturuyordu.

17 Terry Eagleton, Tanrinın Ölümü ve Kültür (İstanbul: Yordam, 2014), 17; Sevcan Öztürk, "Felsefi Teolojide Antrosentrik Dönüş: Teolojik Antropolojiye Bir Giriş”, Beytülhikme Int J Phil 10/4 (2020), 1384. 
baskı altına alan- kurumsal temsillerine karşı ise amansız bir mücadele yürütülüyordu. Bu doğrultuda Aydınlanmanın kurucu muhayyilesinin “din”e karşı çıkışında teolojik gerekçelerden çok siyasal gerekçeler öne çıkıyordu.

Gerçekten de kilisenin ve kutsal kitabın otoritesini ortadan kaldırmayı zorunlu gören Aydınlanma çağının pek çok öncüsü dinlerin tarihsel birikimine açık bir mesafe ile yaklaştıkları halde, doğanın ve aklın ilkeleriyle ulaşılan bir Tanrı fikrine bağlanmaktan da geri durmamışlardı. ${ }^{18} \mathrm{Ne}$ var ki aklın sınırlarına teslim edilmiş bir inanma biçiminin "kitlesel” bir düzeye erişmesi yine pek çoğuna göre oldukça zor bir hedefti. Belki de halkın inançları konusunda daha sabırlı olmak ve "şüphe"nin huzursuzluğu yerine, halkın ve aydınların bilinç düzeyleri açısından bir tür "çifte hakikat"e rıza göstermek daha makul bir tercihti. ${ }^{19}$ Bu sebeple birçoğu Kilisenin ve din adamlarının yerleşik otoritesi yıkıldıktan sonra geçmişin zararsız kalıntılarının ve kitlelerin dayanışmasını teşvik eden kültürel hafızanın birtakım mitik unsurlarının muhafaza edilmesinde bir sakınca görmüyorlardı. ${ }^{20}$ Evrensel bir aydınlanmanın imkanına daha başlangıçta şüphe ve tedirginlikle yaklaşan bu yeni muhayyile nihayetinde dinleri "toplumsal fayda" ekseninde elde tutmakta kararliydı. ${ }^{21}$ Böylece modern toplumun kuruluşunda yeni bir okumayla ele alınan Hristiyanlık, ulus temelli kolektif bilincin inşasına katkı sunacak bir formda varlığını sürdürmeye devam edecekti. Bu elbette teolojik bir okumadan çok siyasal düzeyde toplumun yeniden kurgulanmasına yönelik bir düzenleme fikrine dayanıyordu. Hristiyanlığın kültürel bir fenomene dönüştürülerek toplumsal varlığını sürdürmesi modern ulus devletlerin ortak bir ulusal hafıza yaratmalarını da kolaylaştırıyordu. Özellikle köken mitleri ulusların tarihinin yeni bir aidiyet ve kimlik kurgusuyla yeniden yazılmasına kaynaklık edecek elverişli bir zemin oluşturuyordu. Bu doğrultuda İsa'nın doğumu, öğretileri, mucizeleri, çarmıha gerilmesi ve dirilmesi gibi ana temalar, kültürel hafızada canlı bir biçimde varlığını sürdüren bazı imgeler, figürler ve ritüeller aynı zamanda modern "Batı"nın ortak kültürel mirasını da temsil etme gücüne sahipti. Başka bir deyişle modern Batı toplumlarını dünyanın geri kalanından ayıran ve bir arada tutan en önemli unsur, onun Hristiyanlıkla iç içe geçmiş tarihsel mirasıydı. Son kertede insanın keşif ve ilgilerine sonuna kadar açık, kutsalın her türlü görüntüsünden arındırılmış “yeryüzü cenneti” bile muhayyel bir kimlik tasarımı için "geçmiş”le bir tür mutabakat içinde ancak kurulabiliyordu. ${ }^{22}$

18 Eagleton, Tanrinın Ölümü ve Kültür, 14. Örneğin Voltaire'in kozmolojisini Newton'a, epistemolojisini J. Locke'a borçlu olan deizmi, "kendisine inanabilmeyi haklılaştıracak ölçüde sınırlarına çekilmiş”, evreni ve tabiatı kendi yasalarıyla baş başa bırakmış bir Tanrı tasavvuruna dayanıyordu. Ahmet Çiğdem, Aydınlanma Düşüncesi (İstanbul: İletişim Yayınları, 2012), 48.

19 Eagleton, Tanrinın Ölümü ve Kültür, 14.

20 Charles Taylor, A Secular Age (Cambridge: Harvard University Press, 2009), 240. Peter Gay daha da ileri giderek Aydınlanma çağı filozoflarının modern paganlar olduğunu söyleyecektir. Aktaran Çiğdem, Aydınlanma Düşüncesi, 48.

21 “Toplumsal fayda” söz konusu olduğunda Aydınlanma düşünürleri muhafazakarlığı entelektüel şüpheciliğe tercih ediyordu. Bk. Eagleton, Tanrinın Ölümü ve Kültür, 46.

22 Adorno ve Horkheimer'a göre Aydınlanma'nın kendisi de içsel doğası sebebiyle attığı her adımda mitolojiye karışmaktadır. Aydınlanma düşüncesinin doğa üzerinde kurduğu ilerlemeci bir tahakkümün ve 


\section{Kültürel İnşa}

19. yüzyıldan itibaren toplumla ilişkili olarak ele alınan "kültür" kavramı, bir topluluğa ait kendi içinde tutarlı düşüncelerin, alışkanlıkların, değerlerin, normların, geleneklerin bütünü olarak tanımlanabilii. ${ }^{23}$ Toplumların anlamlandırma ve temsil pratiklerini oluşturan kültür, soyut anlam ve değerlerin, onları yaşayan ve aktaran insanların ve bu değerlerin "taşa kazınmış hali" olan maddi unsurların bütünüdür. ${ }^{24}$ Ne var ki, modern çağda kültürleri hiç olmadığı kadar bütünleștiren ve birleștiren kapitalizm, kültürü her şeye benzerlik bulaştıran bir sisteme dönüştürmüştür. Öyle ki, kapitalist ekonominin ayrılmaz bir parçası haline gelen kültürel üretim, herhangi bir meta üretimi sektöründeki üretim kurallarına uyan bir "endüstri”ye dönüşmüştür. ${ }^{25}$ Bildik şeyleri yeni bir nitelikte birleştiren kültür endüstrisi, taklit olanı mutlak olanın yerine koyarak kitleleri kitlesel üretimin yetkinleştirilmesi yoluyla yeniden biçimlendirir. ${ }^{26} \mathrm{Bu}$ bağlamda Noel'in modern çağa özgü kutsal ve profan ögeleri bir araya getiren seküler formu da esasında kültür endüstrisi bağlamında kazandığ1 araçsal işlevsellik içinde ancak anlaşılabilir.

Modern çağda yaşanan kapsamlı değişim ve dönüşümlerin etkisiyle başlangıçta sahip olduğu dinsel ritüel ve temsillerden bir hayli uzaklaşmış olan Noel, modern çağa içkin değerler dikkate alındığında ilk bakışta bir paradoks olarak görünmektedir. ${ }^{27}$ Gerçekten de aşkınlığın "söylenti konumuna düşürüldüğü" ${ }^{28}$ bir dünyada, yap1sal ve kültürel sekülerleşme süreçlerinde "gündelik hayatın ufuklarından uzaklaş(tırıl)an" kutsalın, karşı konulamaz ve büyüleyici bir biçimde modern insanı cezbetmeye devam etmesi Noel'in küresel ölçekte bu denli yaygın ve coşkulu bir düzeyde kutlanmasını açıklamaya yetmemektedir. ${ }^{29}$

Aydınlanma çă̆ının yükselen değerleriyle tanımlanan modern çağın "yeni insan" tasavvuru her türlü dogmatizmin karşısında duran, "kötü" ve "köleleștirici" olarak kabul edilen mitlerden, ön yargılardan ve hurafelerden uzaklaşmış, kurumsal dinlerin temsil ettiği "eski düzen"i terk ederek "iyi" ve "özgürleștirici" olan "aklın düzeni"ne iman etmiş bir "birey" tasarımına dayanmaktadır. ${ }^{30}$ Modern toplumun kuruluşuna öncülük eden aydın sınıflar, "dinlerin ve geleneklerin boyunduruğundan

aklı merkeze alan yeni bilme biçimlerinin daha köklü bir eleştirisi ise bu ikilinin Aydınlanmanın Diyalektiği başlıklı çalışmasında bulunabilir. Buna göre insanlığı mitik güçlerin esaretinden kurtarmayı vaat eden "araçsal akıl” ın içsel doğası, mitlere yeniden dönülmesine ve daha da mutlak tahakküm biçimlerine yol açmıştır. bk. Aydınlanmanın Diyalektiği, 28.

23 Robert H. Lavenda ve Emily A. Schultz, Kültürel Antropoloji (İstanbul: Doğubatı Yayınları, 2019), 41.

24 Sorokin'in bu üç bileşenli kültür tanımı hakkında bk. Alev Erkilet, “Mahremiyetin Dönüşümü: Değer, Taklit ve Gösteriş Tüketimi Bağlamında ‘İslami Moda Dergileri” Birey ve Toplum 2/2 (2012), 28.

25 Theodor W. Adorno, Kültür Endüstrisi Kültür Yönetimi (İstanbul: İletişim Yayınları, 2011), 19.

26 Adorno, Kültür Endüstrisi Kültür Yönetimi, 109.

27 J.A.R. Pimlott, The Englishman's Christmas (Hassocks: Harvester Press, 1978), Philip Hancock-Alf Rehn, “Organizing Christmas", Organization 18/6 (2011), 737.

28 Peter L. Berger, Melekler Hakkında Söylenti: Modern Toplumda Tabiatüstünün Yeniden Keşfi (İstanbul: Rağbet Yayınları, 2012), 212.

29 Berger, Melekler Hakkında Söylenti, 31.

30 Çiğdem, Aydınlanma Düşüncesi, 14-15. 
kurtarılmış", gelişme, mutluluk, özgürlük ve insana duyulan koşulsuz güven gibi değerler etrafında bütünleşmiş yeni bir toplum hayal ederken, insanın ve toplumun bu kurucu değerler ekseninde yeni baștan kurgulanabileceği öncülünden hareket etmişlerdir. Bu toplumun kültürel inşasında sanata ve edebiyata dönüştürücü birer enstrüman işlevi yüklenmiş, özellikle edebiyat yeni çağın yükselen değerlerini geniş kitlelere aktaracak elverişli bir mecra olarak öne çıkmıştır. 19. yüzyıldan itibaren Noel etrafında geliştirilen popüler edebiyat bunun tipik bir örneğidir.

Charles Dickens'ın A Christmas Carol (1843) (Bir Noel Şarkısı) öyküsü, Noel edebiyatının ilk örneğidir ve halk masallarının başat ögeleriyle çağdaş edebiyatın profan ruhunu bütünleştiren bu öykü kısa sürede Avrupa'da ve Rusya'da büyük bir ün ve şöhret kazanacaktır. Öykünün ilk çevirilerinden sonra Dickens'tan ilham alan ve günümüz Noel ritüellerinin adeta ayrılmaz bir parçası haline gelen Noel hikayeleri etrafında geniş bir edebiyat oluşmuştur. ${ }^{31}$ Kısa zamanda popüler halk edebiyatının özel bir türü haline gelen Noel hikayelerinin en çarpıcı özelliği kutsal öge ve temalarla profan değerleri mezcetmesidir. Dickens'in hikayesinin iki kahramanından birisi olan Crachit, Noel'in seküler ruhunun ideal bir temsilini sunarken, ikinci kahraman Scooge da onun tam aksidir. Dickens öyküsünde belirli bir dogmatik bağlllı̆̆ ifade etmeden Noel'in profan değerlerle yeniden inşa eder. Noel'in Dickensçı ruhu, yoksulları ve öksüzleri bu istisnai zamanın sembolik temsillerine dönüştürerek toplumsal eşitsizliklere dikkat çekerken, Noel zamanının "kutsal” doğası da fakirlere zenginlerin, çocuklara yetişkinlerin katılmasını ve statülerin birbirine yaklaşmasını ifade etmektedir. Ne var ki Dickens'ın işaret ettiği toplumsal erdemleri gündelik hayatın olağan halleri içinde değil, Noel'in olağanüstü "kutsal” ikliminde mucizelerle birlikte ele alması aynı zamanda toplumsal eşitsizlikler ve statüler arasındaki farklılaşmaları meşrulaştırıcı bir işlev de göstermiştir. Nitekim Barnett de Dickens'ın öyküsünün popülerliğini zengin ve fakirler arasındaki sosyal gerilimi yayma yeteneğine bağlamaktadir. $^{32}$

Öte yandan Clement Moore'un Aziz Nicholas'tan Bir Ziyaret (1822) adlı şiiri ve Thomas Nast'ın 1863-1886 yılları arasında yayınladığı illüstrasyonlar da Santa Claus'un modern imajını oluşturacaktır. Thomas Nast'ın Noel'e özgü geleneksel İsa tasvirlerinin yerini alan Santa Claus çizimlerinin seküler dünyaya uyarlanmış bir cazibe ve coşkunluk içinde olması dikkat çekicidir. Genç ve zayıf İsa tasvirlerinin aksine Santa Claus yaşlı ve şişmandır. İsa sıcak çöllerde yaşarken Santa Claus Kuzey

31 Bolton 1987 y1lında Dickens'in öyküsünün radyo, tiyatro, televizyon, opera ve film-çizgi filmanimasyon versiyonları dahil olmak üzere 357 senaryosunu tespit etmiştir. O tarihten bugüne bu öykü çeviri, uyarlama ve taklitleriyle Noel'in kültürel inşasında önemli bir rol oynamıştır. bk. Daniel Miller, “A Theory of Christmas”, Unwrapping Christmas (Oxford: Oxford University Press, 1993), 17. Rusya'da Hans C. Anderson'ın ünlü Kibritçi Kız öyküsü, N. A. Polevoy (Noel Öyküleri, 1826), M. P. Pogodin (Yavuklu, 1828; Vasiliy Gecesi, 1831), O. M. Somov, A. A. Marinski, N. V. Gogol (Noel Arifesi Gecesi, 1831), Baratinski (Yüzük, 1832), N. F. Pavlov (Maskeli Balo, 1835) Dickens'ın öyküsünü takip eden Noel hikayeleridir.

32 Barnett (1954)'ten aktaran Russell Belk, "Materialism and the Making of the Modern American Christmas", Unwrapping Christmas (Oxford: Oxford University Press, 1993), 93. 
kutbunda yaşamakta, İsa'nın çileyle özdeşleşen hayatının aksine neşesi ve kahkahalarıyla dikkat çekmektedir. Belk'e göre İsa'nın kınadığı zenginlik ve lüks tüketim, Santa Claus'un dünyaya sunduğu yaşam enerjisinin kaynağıdır. ${ }^{33}$ İsa'nın somun ve balık mucizesi Noel Baba'nın dipsiz oyuncak torbasını, yemlik hayvanları Ren geyiklerini, çocukların Noel Baba'ya davranış ve tutumlarıyla ilgili verdikleri sözler İsa'ya yapılan duaları, şömine önüne yerleştirilen kurabiye ve süt ise adak kurbanlarını anımsatmaktadır..$^{34}$ Claus'un bir gecede dünyayı dolaşması İsa'nın yolculuklarıyla, Noel şarkıları ise Kilise ilahilerinin seküler versiyonlarıdır. Mesih sevgi ve kurtuluş hediyelerini yeryüzüne getirerek nasıl göğe yükseldiyse, Santa da evlerin bacasından göğe doğru çıkarak gözden kaybolmaktadır. Tıpkı Mesih gibi ölümsüzlüğü ile bilinen Santa Claus, çocukların yıl boyunca ne yaptıklarını bilebilir, onları davranışlarından sorumlu tutar ve ödüllendirir. Öyle ki İsa geleneksel Noel'in ne kadar kahramanıysa, "Noel Baba" da seküler Noel'in o ölçüde kahramanı haline gelmiştir. Üstelik bütün dünya çocuklarına -özellikle kimsesiz ve yardıma muhtaç olanlara- sevinç ve umut dağıtan bu kahraman daima neșeli, sınırsız cömertliğiyle yalnızca ödüllendiren bir karaktere sahiptir.

Geleneksel İsa tasvirlerinin ters yüz edilmesiyle elde edilen Santa Claus figürünün toplumsal statükoyu destekleyen sosyo-politik işlevleri de oldukça dikkat çekicidir. Bu konuda Hobsbawm'ın "icat edilmiş gelenek" kavramsallaştırması oldukça aydınlatıcı ve yol gösterici olabilir. Hobsbawm "gelenek" olarak kutladığımız bazı ritüellerin aslında çok daha yakın geçmişte "yeniden" icat edildiğini ve iletişim araçları sayesinde kitleselleştirildiğini öne sürmektedir. ${ }^{35}$ İcat edilmiş gelenekler geçmişle doğal bir süreklilik içinde geliştikleri izlenimini verseler de aslında belli değer ve davranış normlarının aşılanmasına yönelik bilinçli bir kurguya dayanırlar. ${ }^{36}$ Hobsbawm "modern dünyanın sürekli değişimi ve yenilenmesi ile bu dünyada toplumsal hayatın en azından bazı kısımlarını değişmez ve sabit bir yapıya oturtma girişimleri" arasındaki karşıtlığa dikkat çekerek icat edilmiş geleneklerin zeminini tespit etmeye çalışır. ${ }^{37}$ Geçmişi hatırlatan çeşitli formlara büründürülerek sahnelenen bu amorf gelenekler, yeni durumlara uyarlanarak zoraki tekrarlarla yapay ve uydurma bir geçmiş oluşturulmasina hizmet etmektedir. Richard M. Dorson ise modern çağda otantik sözlü geleneğin ürünleri olarak sunulan fakat aslında kitleleri zihinsel ve ahlaki olarak beslemek için "icat edilmiş" sentetik folklor ürünlerini "fakelore" olarak nitelemektedir. ${ }^{38} \mathrm{Bu}$ ürünler sözlü kültür içinde günümüze kadar ulaşan hikaye-

33 Belk, "Materialism and the Making of the Modern American Christmas", 91.

34 Belk, "Materialism and the Making of the Modern American Christmas", 91.

35 Hobsbawm 1932 yılında İngitere'de başlatılan Kraliyet Noel yayınlarını bu kapsam içinde değerlendirmektedir. bk. "Gelenekleri İcat Etmek”, Geleneğin İcadı, ed. Eric Hobsbawm-Terence Ranger, çev. Mehmet Murat Şahin (İstanbul: Agora Yayınları, 2005), 3.

36 Hobsbawm, "Gelenekleri İcat Etmek", 2-3.

37 Hobsbawm, "Gelenekleri İcat Etmek", 3.

38 Richard M. Dorson 1959 yılında bu anlatıların folklor ürünlerinin geleneksel devamlılı̆̆ının aksine nevzuhur ve "sahte" içeriklerine dikkat çekmek ve bunları gerçek folklor ürünlerinden ayırt etmek için fake-lore (sahte bilgi) kavramını ortaya atmıştır. Dorson'ın “fakelore” kavramsallaştırması daha sonra 
lerden ya da unutulmuş bir geleneğin canlandırılmasından farklıdır. Çünkü en azından bugün sunulduğu şekliyle fakelore ürünleri aslında hiçbir zaman var olmamıştır. $^{39}$ Folklor ürünlerinin temsil ettiği kadim kültürel miras ve değerlerin aksine, sözlü geleneğin manipülasyona elverişli çeşitli sembol ve imgelerinin büsbütün başka bir anlatı içinde yeniden imaline dayanan fakelore, kitle kültürünün üretimine aracılık eden bir tür "fabrikasyon" olarak işlemektedir. ${ }^{40}$ Egemen kültürün değerlerini yüceltmeye hizmet eden kitle kültürünün bu sahte anlatıları, ideolojik ve kültürel hegemonyanın sürdürülmesine hizmet eder. ${ }^{41}$ Nitekim folklor ürünleri kolektif belleğin korunmasına yardımcı olurken fake lore üretimi bunun tam tersidir: "Folklor kolektif belleğin rezervi olduğu sürece bu rezervin fakelore tarafindan tüketilmesi, var olana karşı olan iddiaları açığa çıkaran muhalif ve eleștirel kültürün kaybını temsil eder." ${ }^{42}$

Santa Claus'un modern çağda Noel'in kültürel inşası içinde kazandı̆̆ı yeni form ve sembolik anlamlar Hobsbawm'ın “icat edilmiş gelenek” ve Dorson'ın “fakelore” kavramsallaştırmalarını örneklendiren güçlü ve yaygın bir temsil olarak görünmektedir.

\section{Kutsanmış Haz Politikaları}

Noel'in günümüzde küresel bazdaki yayılımı, kapitalist sistemin ortaya çıkardığı “tüketim kültürü"yle yakından ilgilidir. Tarihsel olarak on beşinci yüzyılın sonlarında Avrupa'da ortaya çıkan, on dokuzuncu yüzyılın sonlarında ise tüm yer küreyi etkisi altına alan kapitalizm, yalnıza değiş tokuş süreçlerinde değil, üretim, dağıtım ve yatırım süreçlerinde de yaygın bir metalaştırma getirmiştir. ${ }^{43}$ Yeni üretim güçlerinin oluşması ve yüksek verimliliğe sahip ekonomik bir sistemin tekelci yapılanmasıyla ortaya çıkan çağdaş kapitalist dünyada tüketim, yeni ve özgün bir toplumsallaşma tarzıdır. Kapitalist sistemin eleştirisini insanın kendi emeğine, üretim sürecine, kendi doğasına ve nihayet kendi türüne “yabancılaşma”sına dayandıran Marx’a göre kapitalist üretim araçları yalnızca insan ve emeği arasındaki mesafeyi arttırmakla kalmamakta, aynı zamanda insanı ürettiği nesnelerin kölesi haline getirir. ${ }^{44}$ Buna göre insanı mekanikleştiren kapitalist dünya sisteminde işçi, emeği ve ortaya koyduğu ürün arasındaki ilişki biçimi üretim araçlarına sahip olanların lehine alınıpsatılan birer "meta" haline getirilmektedir. Dahası kapitalist tüketim toplumunda nesneler, tüm zamanlar boyunca insanların eşyayla kurduğu ilişki biçimlerinden farklı olarak simgesel bir değere ve birer "statü göstergesi”ne dönüştürülmüştür.

folklor çalışmalarında hatırı sayılır bir literatür oluşturmuştur. Dorson'ın ilgili makalesiyle fakelore literatürünün öne çıkan bazı makaleleri için bk. Folklorun Sahtesi Fakelore, haz. Selcan Gürçayır Teke (Ankara: Geleneksel Yayınları, 2018).

39 Dorson, "Folklor ve Fake Lore", Folklorun Sahtesi Fakelore, 11-23.

40 Alan Dundes, Folklore Matter (Konoxville: The University of Tennessee Press, 1989), 40.

${ }^{41}$ William S. Fox, "Folklor ve Fakelore: Bazı Sosyolojik Düșünceler.” Folklorun Sahtesi Fakelore, haz. Selcan Gürçayır Teke (Ankara: Geleneksel Yayınları, 2018), 47.

42 Fox, "Folklor ve Fakelore: Bazı Sosyolojik Düşünceler", 46.

43 Immanuel Wallerstein, Tarihsel Kapitalizm (İstanbul: Metis Yayınları, 2006), 13.

${ }^{44}$ Karl Marx, 1844 El Yazmaları (İstanbul: Birikim Yayınları, 2013), 73 vd. 
"Eşit haz hakkı"45 söylemine dayanan tüketim kültürü, metaların mübadele değerini ortadan kaldırarak malların yarar işlevi yerine "gösterge" işlevini ön plana çıkarmaktadır. Burada artık tüketimin asıl nesnesi metalar değil, Baudrillard'ın deyişiyle nesnelere işaret eden "gösterge"ler olacaktır. ${ }^{46}$ Baudrillard, tüketimi modern kapitalist bireylerin kimlik inşasına hizmet eden bir vitrin olarak göstermektedir. Tüketim toplumunun kalıpları içinde kendi benliğine yabancılaşarak yapay haz ve mutluluklarla oluşturulmuş bir kimliğin peşine düşen modern birey için gerçekliğin yerini suretler almıştır. ${ }^{47}$

Bu yaklaşımın bir adım daha ötesine geçerek bugün gördüğümüz dünyanın bütünüyle bir "gösteri dünyası" olduğunu ileri süren Featherstone da modern toplumda gündelik hayatın dokusuna nüfuz eden göstergelerin ve imajların hızlı akışına dikkat çekmektedir. ${ }^{48}$ Tüketime dayalı bu yeni ilişki biçimi modern dünyayı adeta "metanın kendi yarattığı bir toplumda kendini hayranlıkla seyrettiği” bir gösteri toplumuna dönüştürmüştür. ${ }^{49}$ Esasen gösterinin kendisi yeni değildir, fakat gösteri ve eğlenceyle tüketim dünyasını birbirine bağlayan kültür endüstrisi renk, cam, 1şık, sanat, mağaza vitrinleri ve şık iç dekorasyonlar kullanarak "gösteri”yi her yerde hazır ve nazır bir yaşam formu haline getirmiştir. ${ }^{50}$ Gösteri toplumunun kendine özgü mekanları, bir tür "harikalar diyarı" olarak tasarlanan alışveriş merkezleridir. Günümüzde gösteri ve tüketime adeta kutsal bir nitelik kazandıran alışveriş merkezleri aynı zamanda mabet özelliği gösteren birer "tüketim katedrali”ne dönüşmüş gibidir. ${ }^{51}$ Öyle ki, gösteri ve tüketim nesnelerinin teşhir edildiği alışveriş merkezleri yalnızca sürgit bir tüketim çılgınlığına aracılık etmekle kalmaz, aynı zamanda "sonsuzluğun açık bir biçimde aforoz edildiği modern dünyada”, insan yaşamına sığdırılabilecek sınırsız deneyimler için de bir vitrin işlevi gösterir:

“Artık sonsuza kadar varlığını sürdüren şeyler hakkında endişelenmeyi bıra-

kıp, sonsuzluğun harikalarından hiçbir şey kaybetmemek mümkündür. Hatta insan ölümlü yaşamı içinde sonsuzluğun sunması muhtemel ne varsa tüketebilir. Belki insan ölümlü yaşama biçilen o sınırlı zamanı aşamaz fakat diğer kaldırılması imkânsız sınırlara varmadan önce deneyimlenecek hazların hacmine getirilmiş tüm sınırları aşabilir". ${ }^{52}$

Sosyo-kültürel açıdan esnek üretim tekniklerinin, farklılaştırılmış ve ayrıştırılmış üretim kalıplarının ve gündelik yaşam kültürü açısından akışkan formların yaygınlaşmasıyla karakterize edilen postmodern dünyanın "sahte ihtiyaçlar"a dayalı tüke-

45 Talal Asad, Sekülerliğin Biçimleri Hristiyanlık İslamiyet ve Modernlik (İstanbul: Metis Yayınları, 2007), 184.

46 Jean Baudrillard, Tüketim Toplumu (İstanbul: Ayrıntı Yayınları, 1997), 89.

47 Baudrillard, Tüketim Toplumu (İstanbul: Ayrıntı Yayınları, 1997), 28 vd.

48 Mike Featherstone tüketimi estetik değerlerin taşıyıcıları, yaşam tarzı ve kimliğin göstergeleri olarak ele alır ve bu tüketim teorisini “gündelik hayatın estetikleşmesi” başlı̆̆ı altında açıklar. bk. Postmodernizm ve Tüketim Kültürü (İstanbul: Ayrıntı Yayınları, 2005), 58.

49 Guy Debord, “gösteri”yi modern toplumda sahte bir "kutsal” olarak tanımlamaktadır. bk. Gösteri Toplumu (İstanbul: Ayrıntı Yayınları, 1996), 20.

50 George Ritzer, Büyüsü Bozulmuş Dünyayı Büyülemek (İstanbul: Ayrıntı Yayınları, 2010), 136.

51 Ritzer, Büyüsü Bozulmuş Dünyayı Büyülemek, 33.

52 Zygmund Bauman, Akışkan Hayat (İstanbul: Ayrıntı Yayınları, 2018), 15-16. 
tim ideolojisi aynı zamanda modern totaliterliğin temelini oluşturan bir "sosyal kontrol aracı" olarak dikkat çekmektedir. ${ }^{53}$ Teknoloji, siyaset ve kültürün birbirinden bağımsız olarak tanımlanamayacak düzeyde iç içe geçtiği ve yaşam formlarının giderek bir bütünlük halini aldığı postmodernite, kapitalist sistemin değişimini değil, genişlemesini ve daha kapsamlı hale gelmesini ifade etmektedir. Aydınlanma düşüncesinin seküler muhayyilesinde metafizik kaygıların ve korkularını yenerek "haz peşinde koşan ve acıdan uzak durmaya çalışan" ${ }^{54}$ insanın sıradan deneyimleri, modern toplumda "tüketici, sersemletici, insanlık-dışı bir kölelik" haline gelmiştir. ${ }^{55}$ Noel'in seküler bir içerikle yeniden üretilerek tüketim toplumunun kültürel kalıplarına entegre edilmesi bunun tipik bir göstergesidir. Öyle ki artık Noel ile ilgili kutsal olan, geleneksel olarak İsa'nın doğumunu temsil eden bir zaman değil, "meta mantığı" ve "araçsal rasyonalite"ye dayalı modern kapitalist dünyanın "tüketim festivali"dir. ${ }^{56}$

Öte yandan tüketici davranışları açısından dinlerin ve dindarlık formlarının yönlendirici ve güdüleyici etkisi göz ardı edilemez. Dinler kendilerine özgü inanç, değer ve ibadet sistemleriyle tüketici eğilimlerini ve davranışları üzerinde etkili olurken, dindarlığın dinamik formları tüketicilere yönelik pazar ekonomisinin tüketici odaklı stratejilerinde belirleyici olmaktadır. Tüketim toplumu her şeyden önce çoğulcu yapısıyla dikkat çekmektedir. Dini kurumlar bu çoğulcu yapı içinde birer teşhir merkezi haline gelirken dini gelenekler ve değerler de tüketici malları haline gelerek metalaşmaktadır. Dinin pazar ekonomisine girmesi dini metalaşma örneklerini de beraberinde getirmektedir. Dinsel ögeler tüketim piyasasının çoğulcu yapısı içinde hayat tarzlarının pazarlanmasına dayalı "anlam kompleksleri”yle yan yana konularak tüketicinin beğeni ve tercihlerine sunulmaktadır. ${ }^{57}$ Nitekim geleneksel Noel kutlamalarının naif ritüelleri, tüketim toplumunda yerini abartılı harcamalara, görkemli törenlere, "haz" odaklı eğlencelere ve gösterişli hediyelere birakmıştır. Kuşkusuz toplumsal düzenin ve dayanışmanın sağlanması ve pekiştirilmesinde etkili bir iletişim biçimi olarak hediyeleşme, alışveriş değerinin ötesinde bir sosyal işlev ve değer yüklenmektedir. Geleneksel toplumlarda bir mübadele biçimi olarak toplumsal ilişkiler ağının merkezine yerleştirilen hediyeleşme, aynı zamanda bir sosyal statü, güç ve itibar göstergesi olarak dikkat çekmektedir. ${ }^{58}$ Hediyeleşmenin dayandı̆̆ı karş1lıklılık ilkesi bir taraftan toplumsal ilişkilerin sürekliliğini sağlarken öbür taraftan da kültürel anlam ve değerlerin aktarılmasına aracılık eder. Ne var ki kapitalizmin gündelik totalleştirici eğilimleri tüketim toplumunda hediyeleşmeye yeni anlam ve uygulamalar kazandırmıştır. Bir tahakküm biçimi olarak kültür endüstrisinin biçim-

\footnotetext{
Herbert Marcuse, Tek Boyutlu İnsan (İstanbul: İdea Yayınları, 1990), 8.

Asad, Sekülerliğin Biçimleri, 184.

Marcuse, Tek Boyutlu Insan, 22.

Daniel Boorstin (1973)'den aktaran Belk, "Materialism and the Making of the Modern American Christmas", 331.

57 Featherstone, Postmodernizm ve Tüketim Kültürü (İstanbul: Ayrıntı Yayınları, 2005), 186.

58 Marcel Mauss, Sosyoloji ve Antropoloji (İstanbul: Doğubatı Yayınları, 2011), 201.
} 
lendirdiği tek kutuplu dünyada Noel endüstrisinin ürettiği metalar, "Noel hediyesi" olarak sunuma hazırlandı̆̆ı andan itibaren "tekilleştirilerek" kişiye özel, gizemli bir forma kavuşturulmaktadır. Noel'e özgü hediyeler artık yalnızca kutsal bir ritüelin vazgeçilmez unsurları değil faydacı birer meta olarak “şey”leştirilmiştir.

Kuşkusuz Noel'in metalaşmasının en güçlü temsili aynı zamanda bir tüketim simgesi olarak dikkat çeken Santa Claus (Noel Baba) kültüdür. Thomas Nast'in siyah beyaz illüstrasyonlarında hayat bulan modern Noel Baba figürleri, 1930'da Coca-Cola markasının reklam tasarımlarında firmanın ticari renkleri olan kırmızı ve beyaza boyanmıştır. Şirket 1929 yılında Amerika'da yaşanan ekonomik kriz ortamında Noel Baba'yı "yılbaşı konsepti” içinde yeniden üreterek küresel ölçekli bir "marka miti” olarak tescillemiştir. ${ }^{59}$ Öyle ki Noel haftasında devasa alışveriş merkezlerinin küresel ikonuna dönüşen Noel Baba tasarımları, günümüzde kapitalist kültür endüstrisinin en yaygın ve güçlü imajlarından birisini oluşturmaktadır. Belk’e göre Noel Baba'nın bu ticari formu modern tüketim kültürü sayesinde adeta "materyalizmin ve hedonizmin Tanrısı" haline getirilmiştir. ${ }^{60}$ Noel Baba kültünün merkezinde yer aldığı ve geyikler, yılbaşı ağacı, şükran günü sofraları ve hediyeleşme ritüeli de yılbaşı konseptinin tamamlayıcı parçaları olarak işlevselleştirilmiştir. Nihayetinde bugün bütün dünyada Coca-Cola'nın öncülük ettiği yılbaşı konseptiyle yaygınlaştırılan Noel kutlamaları, kapitalizmin küresel ticari yayılımının en yaygın uygulamalarından birisi olarak dikkat çekmektedir.

\section{Sonuç}

Sonuç olarak bugün Noel, modern çağa özgü kültürel bir inşa olarak dikkat çekmektedir. Modern Batı toplumlarının seküler tahayyülünde Noel gibi mitsel ve arkaik bir geleneğe alan açılmış olması ilk bakışta kayda değer bir çelişkiyi yansıtsa da Noel'in geleneksel envanterinden bugün geriye pek bir şey kalmamıştır. İsa'nın tarihsel temsiliyle pagan geleneklerin mitolojik dünyasını bağdaştıran bir senkretizm konumundaki Noel, modern çağda adeta yeniden icat edilmiştir. On dokuzuncu yüzyılın ortalarında Charles Dickens ve Clement Moore'un öncülük ettiği Noel edebiyatı, Thomas Nast'ın illüstrasyonlarıyla bütünleşerek Noel'in modern imajını oluşturmuştur. Noel'in geleneksel temsillerini ters yüz eden yeni imajı toplumsal eşitsizliklerin ve statüler arasındaki farklılaşmaların meşrulaştırılmasına hizmet eden sosyo-politik işlevleriyle de dikkat çekmektedir.

Noel'in günümüzdeki küresel yayılımı ise daha çok kapitalist sistemin ortaya ç1kardığı tüketim kültürüyle ilgilidir. Hayat tarzlarının dışavurumunu bir gösterge formuna dönüştüren tüketim toplumunda dinsel ögeler de diğer tüketim nesneleri gibi "meta"laştırılarak tüketicinin beğenisine sunulmaktadır. Nitekim bugün profan bir düzenleme içinde alıcıya ulaştırılan bir meta/değer olarak Noel, modern çağda

\footnotetext{
59 George A. Mckay, "Consumption, Coca-Colonisation, Cultural Resistance and Santa Claus." Christmas, Ideology and Popular Culture (Edinbugh: Edinburgh University Press: 2008), 50-70.

60 Belk, "Materialism and the Making of the Modern American Christmas", 329.
} 
“İsa"nın tarihsel temsilini yeniden biçimlendirmekte, Noel’in seküler tahayyülünü yeni kültler, mitik sembol ve temsillerle inşa etmektedir. Günümüzde Noel, arkaik zamanların işlevsel mitik sembolleriyle İsa'nın yeniden tasarımlanmış figürasyonu arasında kurgulanan yeni bir imajı temsil etmektedir. Geçmişe ait değer ve normları hatırlatan ancak ona bambaşka bir karakter kazandıran bu imaj, Noel'in mitolojik sermayesinin metalaştırılmasıyla elde edilmiştir. Bugün artık Noel İsa'nın doğumunu temsil eden "kutsal" bir zamandan bir hayli uzaklaşmış, kapitalizmin küresel ticari yayılımının en yaygın örnekleri arasında yerini almıştır.

\section{Kaynakça}

Adorno, Theodor W. Kültür Endüstrisi Kültür Yönetimi. İstanbul: İletişim Yayınları, 2011.

Adorno, Theodor W. - Horkheimer, Max. Aydınlanmanın Diyalektiği. İstanbul: Kabalcı Yayınları, 1995.

Asad, Talal. Sekülerliğin Biçimleri Hristiyanlık İslamiyet ve Modernlik. İstanbul: Metis Yayınları, 2007.

Baudrillard, Jean. Tüketim Toplumu. İstanbul: Ayrıntı Yayınları, 1997.

Bauman, Zygmund. Akışkan Hayat. İstanbul: Ayrıntı Yayınları, 2018.

Belk, Russell. "Materialism and the Making of the Modern American Christmas". Unwrapping Christmas. ed. Daniel Miller, 319-344. Oxford University Press, 1993.

Berger, Peter L. Melekler Hakkında Söylenti: Modern Toplumda Tabiatüstünün Yeniden Keşfi. İstanbul: Rağbet Yayınları, 2012.

Chadwick, Owen. A History of Christianity. New York: Thomas Dunne Books, 1995.

Cumont, Franz. The Mysteries of Mithra. çev. Thomas McCormack. New York: Cosimo Classics, 2007.

Çiğdem, Ahmet. Aydınlanma Düşüncesi. İstanbul: İletişim Yayınları, 2012.

Demirci, Kürşat. "Hıristiyanlık”. Türkiye Diyanet Vakfi İslam Ansiklopedisi. 17/328-340. İstanbul: TDV Yayınları, 1998.

Debord, Guy. Gösteri Toplumu. İstanbul: Ayrıntı Yayınları, 2005.

Dorson, Richard M. "Folklor ve Fake Lore". Folklorun Sahtesi Fakelore. haz. Selcan Gürçayır Teke, 11-23. Ankara: Geleneksel Yayınları, 2018.

Dundes, Alan. Folklore Matters. Knoxville: The University of Tennessee Press, 1989.

Dürüşken, Çiğdem. Antikçăg'da Yaşamın ve Ölümün Bilinmezine Yolculuk Roma'nın Gizem Dinleri. İstanbul: Arkeoloji ve Sanat Yayınları, 2000. https://doi.org/10.20480/lbr.2016115457

Eagleton, Terry. Tanrinin Ölümü ve Kültür. İstanbul: Yordam Yayınları, 2014.

Eliade. Mircea. Kutsal ve Dindışı. çev. Mehmet Ali Kılıçbay. Ankara: Gece Yayınları, 1991.

Eliade. Mircea. Dinsel İnançlar ve Düşünceler Tarihi II. İstanbul: Kabalcı Yayınları, 2000.

Eliade. Mircea. Mitlerin Özellikleri. İstanbul: Alfa Yayınları, 2016.

Erkilet, Alev. "Mahremiyetin Dönüşümü: Değer, Taklit ve Gösteriş Tüketimi Bağlaminda ‘'̇slami Moda Dergileri”". Birey ve Toplum. $2 / 2$ (2012), 27-40.

Featherstone, Mike. Postmodernizm ve Tüketim Kültürü. İstanbul: Ayrıntı Yayınları, 2005.

Fox, William S. "Folklor ve Fakelore: Bazı sosyolojik Düşünceler”. Folklorun Sahtesi Fakelore. haz. Selcan Gürçayır Teke, 35-50. Ankara: Geleneksel, 2018.

Hancock, Philip-Rehn, Alf. “Organizing Christmas”. Organization 18/6 (2011), 737-745. https://doi.org/10.1177/1350508411428214

Hillerbrand, HJ. “Christmas”. Encyclopedia Britannica; 17 Haziran 2021. https://www.britannica.com/topic/Christmas. 
Hobsbawm, Eric. “Gelenekleri İcat Etmek” Geleneğin İcadı. ed. Eric Hobsbawm-Terence Ranger, 1-18, çev. Mehmet Murat Şahin. İstanbul: Agora Yayınları, 2005.

Işık, Hidayet. "Dini Kökeni Açısından Noel ve Yılbaşı". Necmettin Erbakan Üniversitesi İlahiyat Fakültesi Dergisi 7 (1997), 447-468. https://doi.org/10.51121/akif.2021.13

Katar, Mehmet. “Hristiyanlık’ta İsa'nın Doğumu ile İlgili Kutlamaların Ortaya Çıkışı”. İslamiyat 3 (2000), 115-131.

Lavenda, Robert H. ve Schultz, Emily A. Kültürel Antropoloji. İstanbul: Doğubatı Yayınları, 2019.

Marcuse, Herbert. Tek Boyutlu İnsan. İstanbul: İdea Yayınları, 1990.

Marx, Karl. 1844 El Yazmaları. İstanbul: Birikim Yayınları, 2013.

Mauss, Marcel. Sosyoloji ve Antropoloji. İstanbul: Doğubatı Yayınları, 2011.

Mckay, George A. "Consumption, Coca-Colonisation, Cultural Resistance--and Santa Claus". Christmas, Ideology and Popular Culture. ed. Sheila Whiteley, 50-70. Edinburgh: Edinburgh University Press, 2008. https://doi.org/10.3366/edinburgh/9780748628087.003.0004

Miles, Clement A. Christmas Customs and Traditions, Their History and Significance. New York: Dover Publications, 2011.

Miller, Daniel. “A Theory of Christmas”. Unwrapping Christmas. ed. Daniel Miller, 3-37. Oxford: Oxford University Press, 1993. https://doi.org/10.7146/ta.v0i29.117914

Öztürk, Sevcan. “Felsefi Teolojide Antrosentrik Dönüş: Teolojik Antropolojiye Bir Giriş”. Beytülhikme Int J Phil 10/4 (2020), 1383-1404. https://doi.org/10.18491/beytulhikme.1642

Pimlott, J. A. R. The Englishman's Christmas. Hassocks: Harvester Press, 1978.

Ritzer, George. Büyüsü Bozulmuş Dünyayı Büyülemek. İstanbul: Ayrıntı Yayınları, 2010.

Şenay, Bülent. "Noel”. Türkiye Diyanet Vakfi İslam Ansiklopedisi. 33/201-202. İstanbul: TDV Yayınları, 2007.

Wallerstein, Immanuel. Tarihsel Kapitalizm. İstanbul: Metis Yayınları, 2006. 